\title{
チタン材料における水のガス放出低減に関する研究*
}

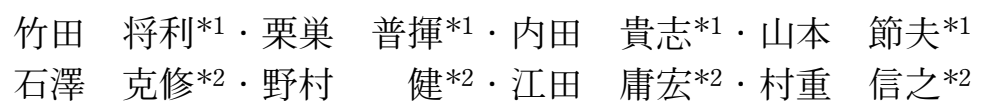

\section{Study for Reduction of Outgassing Property of Adsorbed Water Gas for Improved Surface Finished Titanium Material}

\author{
Masatoshi TAKEDA*1, Hiroki KURISU*1, Takashi UCHIDA*1, Setsuo YAMAMOTO*1, \\ Katsunobu ISHIZAWA*2, Takeru NOMURA*2, Takahiro EDA*2 and Nobuyuki MURASHIGE*2 \\ ${ }^{* 1}$ Graduate School of Science and Engineering, Yamaguchi University, Tokiwadai 2-16-1, Ube, Yamaguchi, 755-8611, Japan \\ ${ }^{* 2}$ CT division San-ai Plant Industries, Ltd, Kazusa Kamatari 1-7-3, Kisarazu, Chiba, 292-0818, Japan
}

(Received November 10, 2009, Accepted February 6, 2010)

\begin{abstract}
This paper addresses the development of the surface finishing for a titanium material and the study for the reduction of outgassing property of adsorbed water $\left(\mathrm{H}_{2} \mathrm{O}\right)$ molecules. Developed surface finishing is composed of the buffing for the reduction of the surface roughness and improved chemical polishing for the thick surface oxide layer compared with the chemical polishing so far. The surface roughness of the surface finished titanium material is reduced $35 \%$ and the thickness of the surface oxide layer increases by $30 \%$. The total amount of thermal desorbed $\mathrm{H}_{2} \mathrm{O}$ gas for the new surface finished titanium is reduced $30 \%$. It is considered that the origin for the decrease of the amount of desorption $\mathrm{H}_{2} \mathrm{O}$ gas is the reduction of the adsorption sites due to the decrease of the surface roughness and the reduction of adsorption energy of $\mathrm{H}_{2} \mathrm{O}$ gas due to the strong surface oxidation for a titanium material.
\end{abstract}

\section{1. はじめに}

近年, 軽量·高強度・低熱膨張率・完全非磁性などの特性 を持つチタンの真空特性を調べ真空装置へ適用する研究開発 が，筆者らも含め日本の幾つかの研究グループを中心に進め られ ${ }^{1-6)}$, 大強度加速器施設 J-PARC の真空ダクトなどにチ タン材料が実用され始めている7)。これまでに我々はチタン 材料用の精密化学研磨処理を開発し, この表面処理を施した $\mathrm{JIS} 2$ 種チタンの $150^{\circ} \mathrm{C} \times 20 \mathrm{~h}$ 真空ベーキング後のガス放出速 度が $7 \times 10^{-13} \mathrm{Pam}^{-1}$ であり, 超高真空仕様の表面処理を施 された既存材料のそれと比較して 2 桁以上低い值を持つこ とを明らかとしてきた ${ }^{4,5)}$. 一方, 真空ベーキングを施さな い場合のガス放出速度は, 表面処理を施された既存材料と比 較して $1 / 5$ 程度の低減であった (4,5). $^{4}$.

一般に真空ベーキングを施さない場合のガス放出源は, 水 を主成分とする吸着気体の放出である. 本研究では, チタン 材料の水のガス放出特性を低減させるために, 表面のさらな る平滑化と強固な表面酸化層の形成に着目し, 精密化学研磨 処理を改良した. 本論文では, 新たな精密化学研磨処理した チタンの表面状態と水のガス放出特性について調べた結果 と, 水のガス放出特性が従来処理よりも低減できた原因につ いて考察したので記述する.

\section{2. 実験方法}

表面処理として, (1)従来のチタン用精密化学研磨処理（処 理 CP）と, 表面平滑化のために, (2)前処理としてバフ研磨

* 平成 21 年 11 月 4 日 第50回真空に関する連合講演会で発表

*1 山口大学大学院理工学研究科（干755-8611 山口県宇部市常盤 台 $2-16-1)$

*2 三愛プラント工業株式会社 クリーンテック事業本部（テ2920818 千葉県木更津市かずさ鎌足 1-7-3)
処理を施した精密化学研磨処理 (処理 $\mathrm{BP}+\mathrm{CP})$, そして強 固な酸化皮膜の形成のために, 研磨液の酸化剂々腐食抑制剂 を調性した新たな化学研磨処理（処理 CPA）を開発し, (3) バフ研磨処理の後 $\mathrm{CPA}$ 処理（処理 $\mathrm{BP}+\mathrm{CPA})$ の 3 種類の 処理を工業用 JIS2 種チタンに施した．なお，本論文ではこ れらの処理を施した試料を $\mathrm{CP}, \mathrm{BP}+\mathrm{CP}, \mathrm{BP}+\mathrm{CPA}$ と呼ぶ.

これらの試料の表面形態は原子間力顕微鏡 $(\mathrm{AFM})$ 観察 により評価した。 JIS2 種チタンに $\mathrm{CP}, \mathrm{BP}+\mathrm{CP}, \mathrm{BP}+\mathrm{CPA}$ 処理を施した $10 \mathrm{~mm} \times 10 \mathrm{~mm} \times 1 \mathrm{mmt}$ の平板試料を準備し た. AFM 測定は, 走査型プロープ顕微鏡（日本電子製： JSPM-4210）を用いた.

試料の表面組成はオージェ電子分光分析 (AES) 装置 (PHI 社製：PHI650）を用い，深さ方向分析により調べた. 分析条件は, 加速電圧を $5 \mathrm{kV}$, 試料電流を約 $20 \mathrm{nA}$, 分析 範囲は $20 \mu \mathrm{m} \times 20 \mu \mathrm{m}$ とした．イオンスパッタリング条件 は, イオン源に $\mathrm{Ar}$ を使用し, 加速電圧を $2 \mathrm{kV}$ として, ス パッタリングレートを約 $5.3 \mathrm{~nm} \cdot \mathrm{min}^{-1}\left(\mathrm{SiO}_{2}\right.$ 換算 $)$ で行っ た.

ガス放出特性は, 昇温脱離（TDS）法により評価した.

Fig. 1 に TDS 測定装置の模式図を示す. 本装置のチャンバ 材料には，低ガス放出な高強度低合金チタン KS100（神戸 製鋼所(侏製) を使用した。測定室はコンダクタンス $3.0 \times$ $10^{-2} \mathrm{~m}^{3} \mathrm{~s}^{-1}$ のオリフィスで隔て, 上流真空室を一定の排気 速度で真空排気できるようにした. 主排気ポンプは 2 台の ターボ分子ポンプを直列接続した. 圧力測定には B-A 型電 離真空を用いた。 TDSスペクトルは四重極質量分析計 （QMS）を用いて測定した. 装置の到達圧力は上流・下流真 空室ともに $1.0 \times 10^{-8} \mathrm{~Pa}$ である.

試料は, CF70フランジ付きの内径 : $\phi 38 \mathrm{~mm}, \mathrm{~L} 404 \mathrm{~mm}$ の円柱管を用いた，今回の実験では，溶接部の酸化スケール からの放出ガスを避けるために, 試料管底面を $20^{\circ} \mathrm{C}$ 一定に 


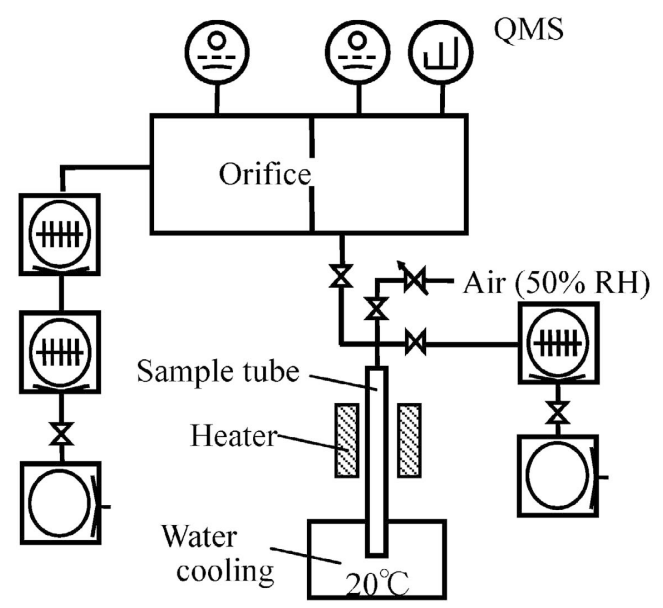

Fig. 1 Schematic illustration of the apparatus of thermal desorption spectroscopy and its specifications.

保ち, 試料管中央部を $\phi 50 \mathrm{~mm}, \mathrm{~L} 150 \mathrm{~mm}$ の円筒形の電気 炉を用いて加熱した。この試料加熱は，PID 制御機能付き のプログラマブル温度コントローラーを用いて, 温度摇らぎ 無く一定の昇温速度で上昇させた. 一方, 温度分布は, 電気 炉の中央部100 mm の範囲で $90 \%$ 以内，炉の端部で70\%であ

った．実験手順を以下に示す。

(1) 試料管を装置に接続し，初期排気を 3 時間行い，装 置部 $120^{\circ} \mathrm{C} ， \mathrm{QMS}$ 部 $140^{\circ} \mathrm{C}$ ，試料管 $150^{\circ} \mathrm{C} て ゙ ， 18$ 時間の 真空ベーキングを行い，その後室温になるまで 5 時間 自然冷却を行った。（初期化）

(2) 相対湿度 $50 \% \pm 0.5 \%$ で大気曝露を 30 分間行った。 そ の後, 試料管は補助排気系と測定部主排気系を用いて 48 時間の真空排気を行った．この間装置部 $120^{\circ} \mathrm{C}, \mathrm{QMS}$ 部 $140^{\circ} \mathrm{C}$ で18時間の真空ベーキングを行い自然冷却した.

(3) その後, 試料管を昇温速度 $3^{\circ} \mathrm{C} \mathrm{min}^{-1}$ で昇温させ, 脱 離ガスのイオン電流変化を QMS で測定した.

\section{3. 結果及び考察}

Fig. 2 (a), (b) に試料 CP と BP $+\mathrm{CP}$ の測定領域 $20 \mu \mathrm{m} \times$ $20 \mu \mathrm{m}$ で測定した AFM 像を示す。 CP 試料では，領域 2 5 $\mu \mathrm{m}$ 程度の凹凸が多数観察されるが， $\mathrm{BP}+\mathrm{CP}$ 試料では比較 的平滑になっていることがわかる. 一方, 領域 $1 \mu \mathrm{m}$ 程度の 先鋭な凹凸は 2 つ試料で同程度である. また, $\mathrm{BP}+\mathrm{CPA}$ の表面形態は BP $+\mathrm{CP}$ と同様であった．Table I の上段に $\mathrm{AFM}$ 像より求めた各種試料の表面粗さ $\mathrm{R}_{\mathrm{a}}$ (中心線平均粗さ) を示す. 3 種類の表面処理した試料の表面粗さを比較すると, $\mathrm{CP}$ 処理にバフ研磨を付加することで, 表面粗さが約 $2 / 3$ に 低減できることがわかる. また, 新規に開発した精密化学研 磨 $\mathrm{CPA}$ は， $\mathrm{BP}+\mathrm{CPA}$ の表面粗さが $\mathrm{BP}+\mathrm{CP}$ と同じである ことから, 従来処理と同程度の平滑化処理が可能であると言 える.

Fig. 3 (a), (b)に試料 $\mathrm{CP}$ と $\mathrm{BP}+\mathrm{CPA}$ のチタン (Ti2), 酸素（O1）そして炭素（C1）元素のオージェ電子分光分析 の深さ方向分析結果を示す. CP 試料の酸素元素 (O1) の強 度は, 表面から深さ $5 \mathrm{~nm}$ （エッチング時間 $1 \mathrm{~min}$ ) 付近で ピーク（元素濃度78\%）となり，深さ10 nm（エッチング時
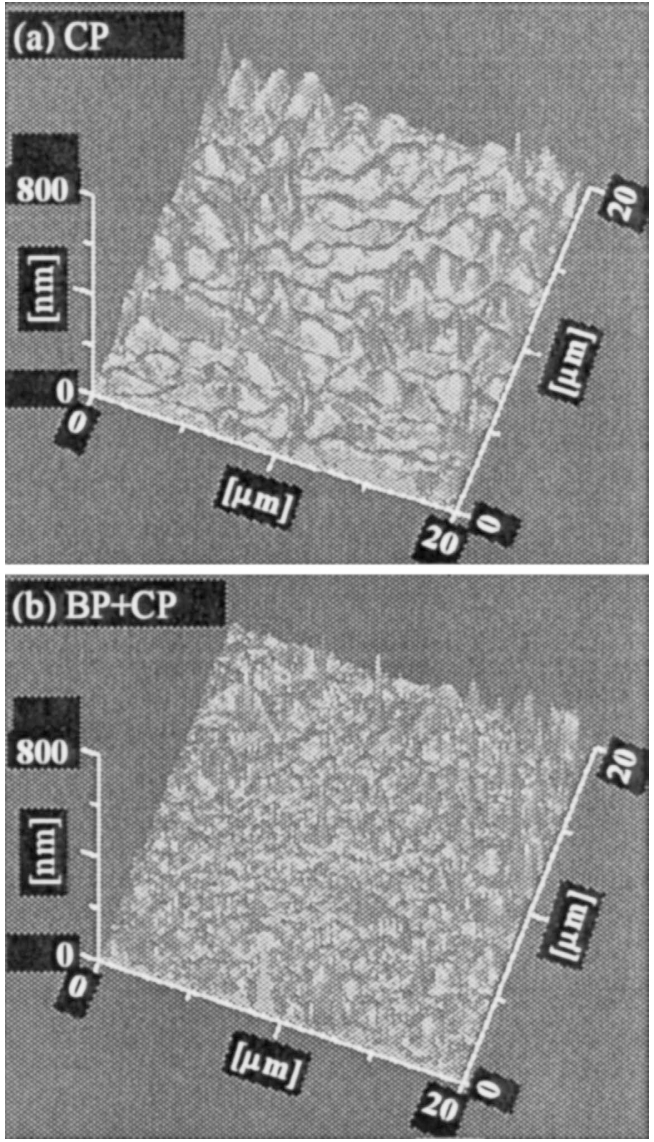

Fig. 2 Atomic force micrographs of chemically polished (CP) titanium sample (a), and buffed and chemically polished (BP $+\mathrm{CP})$ titanium sample (b).

Table 1 Surface roughness and thickness of surface oxide layer of various surface finished titanium samples

\begin{tabular}{l|c|c|c}
\hline \hline \multirow{2}{*}{} & \multicolumn{3}{|c}{ Titanium (JIS grade 2) } \\
\cline { 2 - 4 } & $\mathrm{CP}$ & $\mathrm{BP}+\mathrm{CP}$ & $\mathrm{BP}+\mathrm{CPA}$ \\
\hline Surface Roughness $\left(\mathrm{R}_{\mathrm{a}}\right)$ & $23.7 \mathrm{~nm}$ & $15.1 \mathrm{~nm}$ & $15.6 \mathrm{~nm}$ \\
\hline $\begin{array}{l}\text { Thickness of Surface Oxide } \\
\text { Layer }\end{array}$ & $9.9 \mathrm{~nm}$ & $10.7 \mathrm{~nm}$ & $12.7 \mathrm{~nm}$ \\
\hline
\end{tabular}

間 $2 \mathrm{~min}$ ）付近で最大強度の $1 / 2$ 以下（元素濃度 $32 \%$ ）とな った。 また， $\mathrm{BP}+\mathrm{CP}$ 試料の酸素元素の深さ方向プロファイ ルは $\mathrm{CP}$ 試料のそれと同様であった。一方，強固な酸化皮膜 の形成を目的とした BP $+\mathrm{CPA}$ 試料の酸素強度は表面から急 激に増加し $5 \mathrm{~nm}$ 付近でピーク（元素濃度 $81 \%$ ）となり，深 さ $10 \mathrm{~nm}$ 付近で最大強度の約 $2 / 3$ （元素濃度 $58 \%$ ）となり， さらに深部まで酸素が存在した。このことから， BP+CPA 試料では, 深さ $10 \mathrm{~nm}$ 程度までの酸化度合いが $\mathrm{CP}$ 試料より も高くなっていると考えられる. 酸素元素 (O1) の強度が $1 / 2$ となるところから表面酸化層の膜厚を見積もると, CP: $9.9 \mathrm{~nm}, \mathrm{BP}+\mathrm{CP}: 10.7 \mathrm{~nm}$ そして BP+CPA: $12.7 \mathrm{~nm}$ であっ た. 以上より, $\mathrm{BP}+\mathrm{CPA}$ 試料は, 表面付近の酸化度合いが 高く，そして酸化膜厚も厚くなっていることがわかった.

3 種類の処理を施した試料の真空ベーキングを施さない場 合の昇温脱離スペクトルでは, 室温から $200^{\circ} \mathrm{C}$ の温度範囲に 

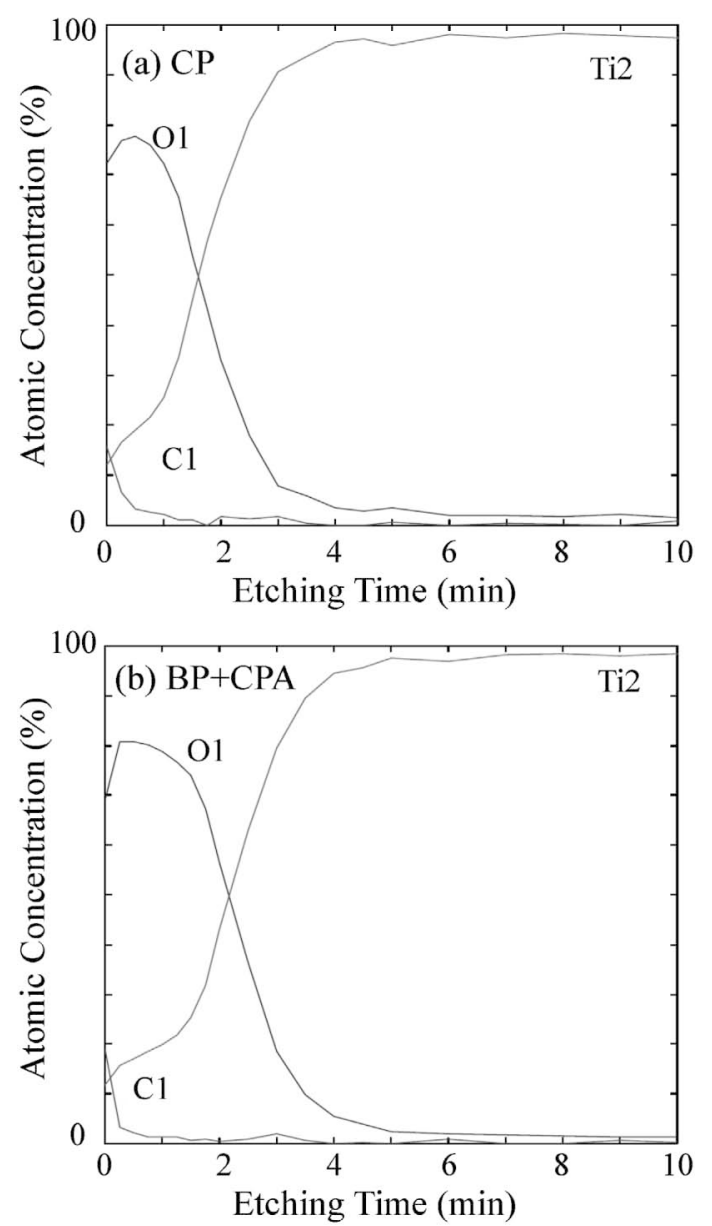

Fig. 3 Depth profiles of titanium, oxygen and carbon elements of the auger electron spectroscopy for chemically polished $(\mathrm{CP})$ titanium sample (a), and buffed and developed chemically polished $(\mathrm{BP}+\mathrm{CPA})$ titanium sample $(\mathrm{b})$.

扔いて，主たる放出ガス成分は水 $\left(\mathrm{H}_{2} \mathrm{O}\right)$ であった. Fig. 4 に試料 $\mathrm{CP}, \mathrm{BP}+\mathrm{CP}$ そして $\mathrm{BP}+\mathrm{CPA}$ の質量電荷比 $18\left(\mathrm{H}_{2}\right.$ O）の昇温脱離スペクトルを示す。水の脱離ガス量は CP> $\mathrm{BP}+\mathrm{CP}>\mathrm{BP}+\mathrm{CPA}$ となって抢り， $\mathrm{BP}+\mathrm{CPA}$ 試料がもっ とも少ないことがわかる. Fig. 5 に各表面処理を施した試 料に抢ける室温から $200^{\circ} \mathrm{C}$ までの水 $\left(\mathrm{H}_{2} \mathrm{O}\right)$ のイオン電流值 の積分量の相対比較を示す．CP 試料の水の脱離ガス量を $100 \%$ とすると，BP+CP 試料は $83 \%$ に， BP + CPA は $68 \%$ に低減できていることがわかる.

$\mathrm{BP}+\mathrm{CP}$ 試料と $\mathrm{BP}+\mathrm{CPA}$ 試料の水の脱離ガス量が $\mathrm{CP}$ の それに対して低減できる理由について Fig. 4 の昇温脱離ス ペクトルから考察する。な扔, 各試料の水の脱離スペクトル の高温領域で現れる脱離のピークは, 昇温時の試料管の温度 不均一によるヒーター端部からの水の脱離に起因していると 考えられる.

$\mathrm{BP}+\mathrm{CP}$ 試料の水の脱離スペクトルを $\mathrm{CP}$ 試料のそれと比 較すると, 脱離の主ピークが $\mathrm{CP}$ 試料では $120^{\circ} \mathrm{C} て ゙$ 現れるこ とに対し, $\mathrm{BP}+\mathrm{CP}$ 試料では $100^{\circ} \mathrm{C}$ 付近と低温側で現れる. また $\mathrm{BP}+\mathrm{CP}$ 試料の水の脱離量は $120^{\circ} \mathrm{C}$ から $200^{\circ} \mathrm{C}$ 温度領 域で大きく減少している。これは, $\mathrm{BP}+\mathrm{CP}$ 試料では化学研 磨の前処理としてバフ研磨処理を施すことで，ミクロな表面 粗さが低減され，化学結合のつなぎ手が多数存在すると考元

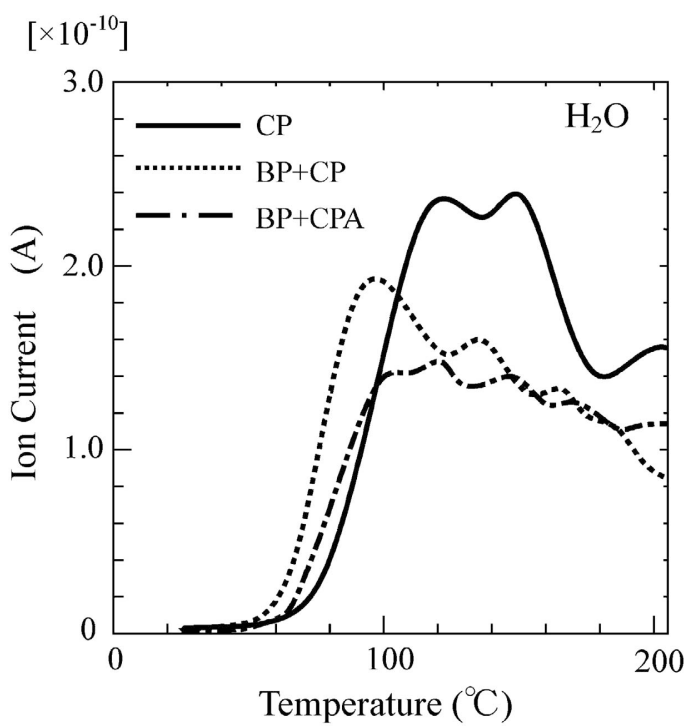

Fig. 4 Thermal desorption spectra of $\mathrm{m} / \mathrm{e}=18\left(\mathrm{H}_{2} \mathrm{O}\right)$ for $\mathrm{CP}$, $\mathrm{BP}+\mathrm{CP}$ and $\mathrm{BP}+\mathrm{CPA}$ titanium samples.

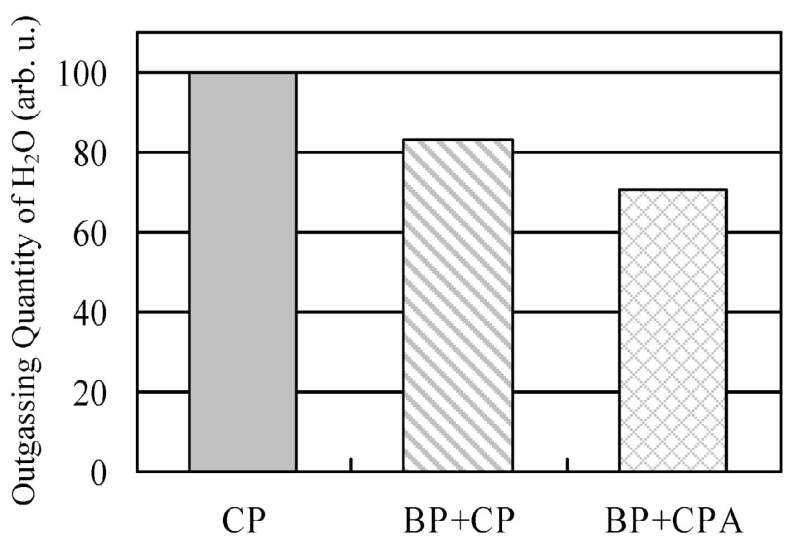

Fig. 5 Comparison of outgassing quantity of $\mathrm{m} / \mathrm{e}=18(\mathrm{H} 2 \mathrm{O})$ for various surface finished titanium samples, $\mathrm{CP}, \mathrm{BP}+\mathrm{CP}$ and $\mathrm{BP}+\mathrm{CPA}$, the outgassing quantity is the summation of ion currents of QMS from RT to $200^{\circ} \mathrm{C}$.

られる表面のステップなどが低減され，表面の化学吸着サイ トが減少したためであると考えられる。また， $\mathrm{BP}+\mathrm{CP}$ 試料 の $100^{\circ} \mathrm{C}$ 付近の脱離のピークも含めた低温側（室温 $\sim 120^{\circ} \mathrm{C}$ ) の水の脱離量が増大する理由は化学吸着サイトが低減した分 だけ物理吸着の表面積が増大したためではないかと推察され る. $\mathrm{CP}$ 試料に対する $\mathrm{BP}+\mathrm{CP}$ 試料の水の低温側の脱離量の 増大量と高温側の脱離量の減少量が異なるのは, 小さい吸着 エネルギーで吸着した水分子が室温の真空排気でも容易に脱 離したためと考えられる.

次に $\mathrm{BP}+\mathrm{CPA}$ 試料の水の脱離量が低減できる原因につい て考察する. $\mathrm{BP}+\mathrm{CPA}$ 試料の水の脱離量は $\mathrm{BP}+\mathrm{CP}$ 試料の それと比較すると, 室温から $120^{\circ} \mathrm{C}$ 温度領域で減少し, 一 方， $120^{\circ} \mathrm{C}$ から $200^{\circ} \mathrm{C}$ 温度領域でほとんぞ同じである。す なわち, 物理吸着した水の吸着量が減少しているものと考元 られる. $\mathrm{BP}+\mathrm{CPA}$ 試料は $\mathrm{BP}+\mathrm{CP}$ 試料と比較して, 表面形 態は同様であるが表面酸化層の表面近傍の酸化度合いが増大 している. 物理吸着エネルギーは, ファンデルワールス相互 
作用と電気双極子・四重極子相互作用が関与する.チタン表 面の酸化度合いが増大することでチタン表面の自由電子が減 少し，水と表面の電気双極子・四重極子相互作用が小さくな ることで, 弱い吸着エネルギーで吸着する水分子が多くな り, 室温の真空排気で脱離する水分子が相対的に増大するこ とにより, 昇温で脱離する脱離量が減少したものと考えられ る.

\section{4. ま と}

チタン材料の水のガス放出特性を低減させるために，(1)表 面のさらなる平滑化のために前処理としてバフ研磨と(2)強固 な表面酸化層の形成のために改良した精密化学研磨処理を開 発し, 表面形態, 表面層組成そして水の昇温脱離特性を調べ た.その結果, 表面平滑化処理により，表面粗さが約 $2 / 3$ に低減し, 酸化処理により表面付近の酸化度合いが高く, そ して酸化膜厚も厚くなることがわかった. 従来の精密化学研
磨処理したチタンと比較し, バフ研磨と表面酸化を促進した 精密化学研磨処理したチタンの水の昇温脱離量は, 約 $70 \%$ に低減できることがわかった。

\section{[文献}

1) M. Minato and Y. Itoh: J. Vac. Sci Technol. A, 13 (1995) 540. 2) Y. Moromoto, A. Takemura, Y. Muroya, M. Uota, Y. Sato and Y. Saito: Shinku, 45, (2002) 665.

3) H. Kurisu, T. Muranaka, N. Wada, S. Yamamoto, M. Matsuura and M. Hesaka: J. Vac. Sci. and Technol. A, 21 (2003) L10.

4) H. Kurisu, G. Kimoto, H. Fujii, K. Tanaka, S. Yamamoto, M. Matsuura, K. Ishizawa, T. Nomura and N. Murashige: Shinku, 49, (2006) 254.

5) K. Ishizawa, H. Kurisu, S. Yamamoto, T. Nomura and N. Murashige: Journal of Physics: Conference Series 100, (2008) 092023.

6) H. Kurisu, K. Ishizawa, S. Yamamoto, M. Hesaka and Y. Saito: Journal of Physics: Conference Series 100, (2008) 092002.

7) Y. Saito: Vacuum, 73 (2004) 181. 